\title{
A United Independence Front? Policy Divergence between the Scottish Pro-independence Parties in the Context of the 2016 Scottish Parliament
} Election

Un front indépendantiste uni? Les divergences programmatiques des partis indépendantistes écossais dans le cadre des élections législatives écossaises de 2016

Nathalie Duclos

\section{OpenEdition}

Journals

Electronic version

URL: http://journals.openedition.org/rfcb/1589

DOI: $10.4000 /$ rfcb.1589

ISSN: 2429-4373

Publisher

CRECIB - Centre de recherche et d'études en civilisation britannique

\section{Electronic reference}

Nathalie Duclos, «A United Independence Front? Policy Divergence between the Scottish Proindependence Parties in the Context of the 2016 Scottish Parliament Election », Revue Française de Civilisation Britannique [Online], XXII-4 | 2017, Online since 15 November 2017, connection on 01 May 2019. URL : http://journals.openedition.org/rfcb/1589; DOI : 10.4000/rfcb.1589

This text was automatically generated on 1 May 2019.

\section{c)}

Revue française de civilisation britannique est mis à disposition selon les termes de la licence Creative Commons Attribution - Pas d'Utilisation Commerciale - Pas de Modification 4.0 International. 


\section{A United Independence Front? Policy Divergence between the Scottish Pro-independence Parties in the Context of the 2016 Scottish Parliament Election}

Un front indépendantiste uni? Les divergences programmatiques des partis indépendantistes écossais dans le cadre des élections législatives écossaises de 2016

Nathalie Duclos

\section{Introduction}

This article examines policy divergence between the Scottish pro-independence parties in the context of the 2016 Scottish Parliament election. It focuses on the main proindependence parties, namely the four pro-independence parties that were able to field candidates in each of the Scottish regions. Those were the Scottish National Party, the Scottish Greens (which have officially supported independence since 2005'), a new socialist alliance called RISE, and another socialist party called Solidarity. As can be seen in the following table, which presents a list of all of the pro-independence candidates in the 2016 election, the only existing pro-independence party that has been excluded from the analysis is the newly-created Scottish Libertarian Party, a party which only fielded four candidates across the whole of Scotland and therefore played an extremely marginal role (if any at all) in the election campaign. 
Table 1: Pro-independence candidates, 2016 Scottish Parliament election

\begin{tabular}{|c|c|c|c|c|c|c|}
\hline & \multicolumn{2}{|c|}{$\begin{array}{l}\text { Constituency candidates } \\
\text { (73 constituencies) }\end{array}$} & \multicolumn{2}{|c|}{$\begin{array}{l}\text { Regional } \\
\text { candidates } \\
\text { (8 regions) }\end{array}$} & \multicolumn{2}{|l|}{$\begin{array}{l}\text { Total } \\
\text { candidates }\end{array}$} \\
\hline \multicolumn{2}{|l|}{ SNP } & \multicolumn{2}{|c|}{73 candidates } & \multicolumn{2}{|c|}{$\begin{array}{l}\text {-all regions } \\
-96 \text { candidates } \\
(12 \text { per region })\end{array}$} & 169 \\
\hline Scottish Gree & ens & \multicolumn{2}{|c|}{$\begin{array}{l}3 \text { candidates } \\
\text { (Glasgow Kelvin, } \\
\text { Edinburgh Central, } \\
\text { Coatbridge \& Chryston) }\end{array}$} & \multicolumn{2}{|c|}{$\begin{array}{l}\text {-all regions } \\
-66 \text { candidates } \\
\text { (6 to } 9 \text { per region) }\end{array}$} & 69 \\
\hline \multicolumn{2}{|c|}{$\begin{array}{l}\text { RISE-Scotland's Left } \\
\text { Alliance }\end{array}$} & \multicolumn{2}{|c|}{0 candidate } & \multicolumn{2}{|c|}{$\begin{array}{l}\text {-all regions } \\
-40 \text { candidates } \\
\text { ( } 2 \text { to } 8 \text { per region) }\end{array}$} & 40 \\
\hline \multicolumn{2}{|l|}{ Solidarity } & \multicolumn{2}{|c|}{0 candidate } & \multicolumn{2}{|c|}{$\begin{array}{l}\text {-all regions } \\
-40 \text { candidates } \\
\text { ( } 4 \text { to } 6 \text { per region) }\end{array}$} & 40 \\
\hline \multicolumn{2}{|c|}{ Scottish Libertarian Party } & \multicolumn{2}{|c|}{$\begin{array}{l}1 \text { candidate } \\
\text { (Edinburgh Central) }\end{array}$} & \multicolumn{2}{|c|}{$\begin{array}{l}-3 \text { regions } \\
\text { (West of Scotland, } \\
\text { Mid Scotland \& Fife, } \\
\text { North East Scotland) } \\
-3 \text { candidates } \\
\text { (1 per region) }\end{array}$} & 4 \\
\hline
\end{tabular}

SOURCE: FIgURES COMPILED BY THE AUTHOR AND BASED ON THE INFORMATION GIVEN ON THE WEBSITES OF EACH PARTY.

Looking at policy divergence within this group of four parties is particularly relevant as all of them claim to be both pro-independence and left-wing. They might therefore be expected to share a certain number of policies or at least priorities; and yet, as will be demonstrated, the 2016 Scottish Parliament election campaign was defined in a large part by the policy differences between them.

This is because one of the only unknowns of the election was the size of the SNP's expected victory and whether the smaller pro-independence parties might manage to split the independence vote and cost the SNP its overall majority in the Scottish Parliament. ${ }^{2}$

To put the 2016 election into perspective, it is important to understand that the past ten years in Scotland have been characterised by a series of dramatic ballots with very unexpected results. First, there was the 2007 Scottish Parliament (or "Holyrood") election, which the SNP won by the tiniest of margins (one seat only) but which made it into a government party for the first time in its history. This was followed by the 2011 
Holyrood election, when the SNP was the first party to ever win an overall majority of seats in the Scottish Parliament: not only was this completely unexpected considering the nature of the electoral system, but it also gave the SNP a political mandate to organise an independence referendum, something that the party was unprepared for. Then, in 2014, there was the referendum itself, which was won by the pro-UK, Unionist side, but by a smaller margin than had originally been expected. And finally, the 2015 British General Election saw the SNP almost wipe out all of its competitors, the three main Unionist parties (Labour, the Conservatives and the Liberal Democrats) being left with only one seat each; although the SNP's 2015 victory in Scotland was not unexpected, the scale of its victory was.

This long-term perspective is necessary to understand why the 2016 Holyrood election campaign was widely felt to be "boring", with one political commentator complaining that "[t]he only thing more boring than the 2016 Scottish election" had been "hearing people talk about how boring" it was. ${ }^{3}$ An SNP victory was always a given, considering its huge and consistent lead in the polls, and there were only two unknowns: would the SNP win an overall majority of seats or a relative one, and might the Conservatives beat Labour into second place? Linked to the first question was that of the results which the small proindependence parties might be able to achieve. As those questions were at the heart of the campaign, they largely informed the strategies of both the SNP and the smaller proindependence parties - which is what this paper will look into first. It will then focus on three issues which were at the heart of the election campaign and which are major areas of policy divergence between the SNP on the one hand, and the smaller pro-independence parties on the other hand, namely income tax, fracking and the issue of a second independence referendum. The underlying aim of this article is to question the existence of a united independence front in Scotland.

\section{The pro-independence parties' campaign strategies in the 2016 Holyrood election}

On 24 April 2016, just a few weeks before the election, the Sunday Herald ran on its front page a headline titled "Battle for the second vote of independence supporters". As one commentator confirmed just a few days later:

The most contentious topic of debate so far has been between supporters of independence. And it's not about policies but about how much the SNP are going to win by and if there is a tactical benefit for SNP supporters in lending their second vote to the smaller parties. ${ }^{4}$

The 2016 Holyrood election witnessed a striking convergence in the campaigning strategies of the smaller pro-independence parties, which, faced with a sure SNP win, concentrated on attracting people's second votes. The specific electoral system at work for Holyrood elections (known as the Additional Member System or the Mixed Member Proportional System) gives people two votes: a first one for a constituency candidate (who, most of the times, represents a political party), and a second one for a regional list of candidates proposed by a political party. Constituency candidates are elected by the majoritarian "First Past the Post" system, while regional candidates are elected by a proportional system - which is why smaller parties tend to target the second vote. The battle for second votes became fierce when a report published by political scientist John Curtice suggested that due to the workings of the electoral system, in which the second 
vote mathematically rebalances the first one, independence supporters might waste their second vote if they voted for the SNP twice, and might therefore consider lending it to one of the smaller pro-independence parties instead. The logic was that given the SNP's lead on the first vote, the party might not win many seats through the second vote, so that if one's priority was to get as many independence supporters elected as possible, then it might make more sense to use the second vote to try and get Green or socialist candidates into the Scottish Parliament.

By the time that the report was published, the smaller pro-independence parties had already chosen to target the second, regional vote. As table 1 shows, the two socialist parties/alliances, RISE and Solidarity, only stood in the regional lists. As for the Greens, they presented candidates in every region but only fielded three constituency candidates. The campaign message of those three smaller parties was adapted to fit this regional strategy. It was based on two central ideas: that different pro-independence viewpoints should be represented in the Scottish Parliament, and that Scotland needed representatives who could challenge the SNP from the left. Both ideas were encapsulated in the introduction to the Greens' manifesto: "Holyrood - and Scotland - needs diverse politics and progressive champions to hold the biggest parties to account." ${ }^{5}$ Similarly, as early as November 2015 RISE argued that:

The polling has been consistent for months: the SNP will win another majority government on the constituency vote alone; voting for the SNP on the second vote is a wasted vote for indy supporters and will mean less RISE and Green MSPs and more Labour and Tory MSPs. One of the strengths of the independence movement was its diversity, now we have a unique opportunity for that diversity to be reflected in the Scottish Parliament. (...) It's for the good of the whole independence movement if the indyleft voice is part of the debate at Holyrood. ${ }^{6}$

As for the SNP, its overall strategy, summed up in the hashtag "Both Votes SNP" which appeared at the bottom of every page in its election manifesto, mainly aimed at countering the arguments made by the smaller pro-independence parties. Interestingly, the "Both Votes SNP" slogan had already figured in the SNP's previous Holyrood election campaign. On the day before the 2011 election, the then Deputy First Minister Nicola Sturgeon had stated that:

On the doorstep, online and in the media we will be taking every opportunity to ensure Scotland's voters re-elect an SNP Government with both votes. Tomorrow it has to be both votes SNP for a five-year Council Tax freeze and Alex Salmond for First Minister.?

At the time, the idea had been to fight any kind of split vote. But in 2016, the "Both Votes SNP" slogan clearly targeted independence supporters who might be tempted to vote SNP first and Green or socialist second. This was made abundantly clear in a press article written by rising SNP star Mhairi Black MP, in which she denounced the argument according to which a second vote for one of the smaller pro-independence parties would be the best way to "maximis[e] the pro-independence strength in parliament" as "wrong, misguided and - in some cases - profoundly disingenuous". ${ }^{8}$ Her words reflect the anger felt by many SNP sympathisers at the smaller pro-independence parties' campaign strategy, for the reasons summed up in the following words by a leading pro-independence journalist:

The SNP has no shortage of opponents. Another political party - especially one born out of the Yes campaign [RISE] - lobbing grenades at it isn't the best way to defeat a Unionist movement now on its knees. (...) Weaken the Nats and you always weaken the independence movement. ${ }^{9}$ 
As explained previously, the smaller pro-independence parties' campaign strategy was based on the message that Scotland needed diverse pro-independence voices and that it needed leftwing challengers to the SNP. The Greens and the socialists therefore had to demonstrate that their outlook was both different from the SNP's and more leftwing. Policy divergence on the independence side was therefore at the heart of the election campaign.

\section{Policy divergence of the pro-independence parties on the occasion of the 2016 Holyrood election}

The two-year-long independence referendum campaign had revealed two major areas of policy convergence, but also a certain number of big policy differences within the proindependence camp which, at the time, had included three parties: the SNP, the Greens and the Scottish Socialist Party (SSP). Although those parties had agreed on two key issues - independence as well as opposition to nuclear weapons - policy divergence had been marked in three areas: defence (they disagreed over an independent Scotland's membership of NATO); macro-economic affairs (they disagreed over what currency an independent Scotland might have); and constitutional affairs (they disagreed over Scotland remaining a monarchy or becoming a republic). Interestingly, all of those areas of policy convergence and divergence are reserved matters, not devolved ones. In that respect, what was particularly interesting about the 2016 Holyrood election is that it gave air to some of the policy differences between the pro-independence parties in devolved areas, and not reserved ones, for the first time.

A comparison between the election manifestos of the four main pro-independence parties allows us to identify the main areas of policy divergence between them. This article focuses on those differences that drew the most media attention and that were therefore at the heart of the election campaign. Based on this criterion, three policies or policy areas stand out, namely taxation (this articles takes the example of income tax), fracking and the issue of a second independence referendum.

In policy terms, taxation was at the heart of the campaign, and it was also the key area where the pro-independence parties - and in fact all Scottish parties - most diverged. The most prominent differences were in terms of income tax proposals, which, as noted by one commentator, is particularly significant as parties' income tax policies “feed down on their ability to enact other policies". ${ }^{10}$ The pro-independence parties diverged over the issue of how to use the Scottish Parliament's new income tax powers, gained as a result of the Scotland Act 2016. The current UK-wide income tax rates and bands, which the Scottish Parliament now has the power to vary, are presented in table 2.

Table 2: Current British Income Tax rates and bands (2016-17)

\begin{tabular}{|l|l|l|}
\hline Band & Taxable income & Tax rate \\
\hline Personal Allowance & Up to $£ 11,000$ & $0 \%$ \\
\hline Basic rate & $£ 11,000$ to $£ 43,000$ & $20 \%(20 p$ in the $£)$ \\
\hline Higher rate & $£ 43,001$ to $£ 150,000$ & $40 \%(40 p$ in the $£)$ \\
\hline
\end{tabular}


\begin{tabular}{|l|l|l|}
\hline Additional rate & over $£ 150,000$ & $45 \%(45 p$ in the $£$ ) \\
\hline
\end{tabular}

Source: https://www.gov.uk/income-tax-rates/current-rates-and-allowances (accessed on 27 May 2016)

The Scotland Act 2012 had already given Holyrood the power to set a Scottish rate of income tax, a power which had only come into effect in April 2016, just before the Holyrood election which this article focuses on. This new power had meant that every tax year, 10 percentage points (or "10p in the pound", in common parlance) would be deducted from each of the 3 income tax rates (the basic, higher and additional rates) for Scottish taxpayers; the Scottish Parliament would then set an annual Scottish rate, which would lead to Scottish taxpayers paying more, less or as much income tax as English taxpayers. ${ }^{11}$ However, the Scotland Act 2012 had not given Holyrood the power to vary the Scottish rate of income tax by band: the same rate had to be applied equally to all tax bands. This is one of the major changes brought about by the Scotland Act 2016 (which received royal assent in March). From the next tax year (i.e. 2017-18), the Scottish Parliament will be able to set both the income tax rates and the band thresholds (excluding the personal allowance, i.e. the amount of non-taxable income).

As could be expected given the Scottish Parliament's brand new tax powers, income tax was a major battleground in the 2016 election. Scottish First Minister and SNP leader Nicola Sturgeon made this quite clear when she noted that the election should not be taken lightly, not least because it was "the first one in which people [were] electing a government to exercise Scotland's new tax and welfare powers." ${ }^{12}$ Her party made three pledges concerning income tax. The first was to increase the amount of income exempt from income tax; given that the Scottish Parliament does not have the power to vary the personal allowance, the way in which it proposed to do this was to create a new zero-rate tax band. The second pledge was to freeze the basic rate of income tax throughout the next parliament. The third and most controversial one was to cancel in Scotland the British Chancellor's plans to raise the higher rate threshold from $£ 43,000$ to $£ 45,000,{ }^{13}$ plans which amount to a tax reduction for some of the highest earning taxpayers. This pledge was controversial because it was deemed not radical enough: as noted by all the other left-wing parties in Scotland, cancelling a tax reduction for some of the highest earners is not the same thing as taxing the rich more, ${ }^{14}$ and what was notably absent from the SNP's manifesto was a pledge to raise the additional tax rate from $45 \mathrm{p}$ to 50p. This was somewhat surprising, as in its 2015 British election manifesto, the SNP had pledged to back proposals to return the top rate of income tax to 50p UK-wide. ${ }^{15}$

By contrast, both the Greens and RISE (Solidarity did not mention income tax in its manifesto) proposed to raise the top rate, not from $45 \mathrm{p}$ to $50 \mathrm{p}$, but to $60 \mathrm{p}$, which drew quite a lot of media attention. Simply put, the Greens planned to make those earning less pay less and those earning more pay more. More precisely, they proposed to change the three rates of income tax. The basic rate of $20 \%$ would be replaced by 2 bands (an $18 \%$ and a $22 \%$ band), which would amount to re-introducing a lower rate of income tax and therefore to a tax reduction for low earners. By contrast, the other two rates (the higher and additional ones) would be increased, respectively from $40 \%$ to $43 \%$, and from $45 \%$ to $60 \%{ }^{16}$ As for RISE, it pledged both to raise the additional rate to $60 \mathrm{p}$ and to create a new band covering the top earners amongst the higher rate taxpayers: those earning between $£ 50,000$ and $£ 150,000$ per year would be levied at $45 p$ in the pound instead of $40 p \cdot{ }^{17}$ We see 
that the Greens and RISE both planned to tax the top earners more so as to mitigate the effect of British government cuts, something that the SNP clearly shied away from.

Policy divergence on tax was used by the smaller pro-independence parties as a central campaigning plank. The SNP's fiscal prudence seemed at odds with its anti-austerity rhetoric, and it allowed the Greens and RISE to portray themselves as the only real leftwing pro-independence alternative in Scotland. How did the SNP answer the accusation that it was not leftwing enough and how did it justify its decision not to raise the top rate of income tax? As one SNP candidate put it during election hustings in Glasgow, as long as Scotland remains part of the UK, the SNP believes in raising the top tax rate throughout the UK, but it does not believe in a 50p or 60p tax rate in Scotland only. The fear is, in the candidate's words, that "money would leave Scotland" (meaning that the top earners might be tempted to move to another part of the UK), and this was not a risk that the SNP was ready to take: "when in government", the SNP candidate added, "we need to be responsible". ${ }^{18}$ The SNP manifesto also explained the decision not to raise the income tax for the highest earners in the following way: "While the Scottish Government does not control the rules on income tax avoidance, there is a risk that an increase in the Additional Rate in Scotland could put revenue at risk." It was added that the SNP might "consider raising the additional rate from 45p to 50p from 2018/19 onwards", but only after conducting a risk assessment on the issue..$^{19}$ In summary, the SNP justified its rather conservative stance on income tax in the name of government responsibility.

Policy divergence between the SNP on the one hand, and the smaller pro-independence parties on the other hand, was also obvious over the contentious issue of "fracking" (hydraulic fracturing). The Greens, RISE and Solidarity agreed that fracking should be totally outlawed (a position also shared by Labour and the Liberal Democrats). By contrast, the SNP's position was to have a moratorium on fracking while both additional research and a public consultation on the issue were conducted. The SNP claimed to be " deeply sceptical about fracking", and its manifesto committed it to a policy of no fracking unless "it [could] be proven beyond any doubt that there is no risk to health, communities or the environment". ${ }^{20}$ The SNP also argued that a moratorium was better than a ban, as a ban could be challenged in court by the big fracking companies. However that may be, the SNP's position on fracking was less straightforward (and more worrying in the eyes of anti-fracking activists) than that of the other parties. This was confirmed on 1 June 2016, when the party abstained in the Scottish Parliament on a motion which called for "an outright ban on fracking". ${ }^{21}$ However, the motion was carried despite the SNP's abstention, which increases the pressure on the SNP to support a total ban.

Finally, on the issue of a second independence referendum (or "indyref", as it is commonly known in Scotland), the 2016 election saw the convergence of the two socialist groupings, on the one hand, and of the Greens and the SNP on the other hand. RISE and Solidarity both made the holding of a second independence referendum one of their utmost priorities, and they both argued for it to take place in the course of the next parliament. RISE pledged to table a resolution on the Scottish Parliament's "right to a mandate to call for and achieve a second referendum on independence, at the time of its choosing, during the lifetime of this Parliament", ${ }^{22}$ and Solidarity to introduce a Private Member's Bill calling for a referendum to be held in $2018 .{ }^{23}$ Both political groupings insisted on the importance of Scotland having a mandate to call for a second referendum, but while RISE explained how Scotland might gain such a mandate, Solidarity argued that Scotland already had one, because the previous independence referendum had been rigged ${ }^{24}$ and 
because the pro-independence SNP had then gone on to win almost all Scottish seats in the 2015 UK General Election. By contrast, the SNP and the Greens refused to make a priority of the issue of a second independence referendum - to the point that it did not even figure on the two-page-long list of SNP priorities at the beginning of its manifesto. Neither party committed to asking for the holding of another referendum in the course of the next parliament. As Nicola Sturgeon declared at the launch of her party's manifesto, " setting the date for a referendum before a majority of the Scottish people have been persuaded that independence - and therefore another referendum - is the best future for our country is the wrong way round". ${ }^{25}$ Moreover, both the SNP and the Greens insisted that it was for the people of Scotland to decide when a second referendum should be held. However, both remained deliberately vague on the issue of what might constitute a popular mandate for a second independence referendum. The SNP spoke of the need for "clear and sustained evidence that independence has become the preferred option of a majority of the Scottish people", ${ }^{26}$ and the Greens of a petition presented in parliament and signed by "an appropriate number of people"27 (though admittedly, their website did give a precise figure of one million signatures). The only real difference between the positions of the Greens and the SNP on a second independence referendum was that the SNP identified two possible routes to a second "indyref": not just a popular mandate, but also what it called "a significant and material change in the circumstances that prevailed in 2014, such as Scotland being taken out of the EU against our will"28 - a phrase which has been at the centre of debates since the 2016 EU membership referendum, when Scotland voted very clearly to remain in the EU while the UK as a whole voted to leave it.

\section{Conclusion}

The underlying aim of this article has been to examine to what extent the Scottish proindependence parties concur beyond their convergence on the general policy aim of independence. The Scottish independence referendum campaign seemed to have given birth to a united independence front in Scotland, all the more so since all of the proindependence parties had claimed to belong to the wider left movement. The campaign had also revealed crucial policy and ideological differences on the pro-independence side over the currency, NATO and the monarchy. However, at the time, independence supporters had downplayed their differences and attempted to present a united front behind the common goal of independence, arguing that divisive questions would be settled democratically after that goal had been attained. They had also insisted on their overall ideological convergence or at least compatibility, due to their common support for independence, but also to their common opposition to austerity politics and support for greater social justice. The return to electoral politics on the occasion of the 2015 British General Election could have led to cracks appearing in the independence front; in the event it did not, ${ }^{29}$ as there was hardly any competition on the pro-independence side: the SSP only fielded four candidates and the Greens competed in about half of the Scottish constituencies, meaning that dissensions between the pro-independence parties were once again largely hidden from view. The 2016 Scottish Parliament election was therefore the first post-referendum election to bring those dissensions to the fore. What is more, it was the first time that policy divergence in devolved matters and not just in reserved ones became an issue. This policy divergence fed into the smaller parties' electoral strategy and led to a bitter battle of words between independence supporters. 
In the wake of the 2016 election, many SNP supporters were very angry at the smaller pro-independence parties, which they blamed for the SNP losing its overall majority (which it had had since 2011). However, the election results on the pro-independence side (which are presented in table 3 ) must be put into perspective.

Table 3: Pro-independence parties, winning candidates, Scottish Parliament election 2016

\begin{tabular}{|l|l|l|l|}
\hline & $\begin{array}{l}\text { Constituency } \\
\text { seats } \\
\text { (out of 73) }\end{array}$ & $\begin{array}{l}\text { Regional } \\
\text { seats } \\
\text { (out of 56) }\end{array}$ & $\begin{array}{l}\text { TOTAL winning candidates (out } \\
\text { of 129) }\end{array}$ \\
\hline SNP & $59(+6)$ & $4(-12)$ & $63(-6)$ \\
\hline Scottish Greens & 0 & $6(+4)$ & $6(+4)$ \\
\hline $\begin{array}{l}\text { RISE : Scotland's Left } \\
\text { Alliance }\end{array}$ & 0 & 0 & 0 \\
\hline Solidarity & 0 & 0 & 0 \\
\hline Scottish Libertarians & 0 & 0 & 0 \\
\hline
\end{tabular}

First, the SNP is just two MSPs-short of an overall majority. Second, the proindependence side still has a total majority in parliament (with 69 seats out of 129). Thirdly, and finally, the risk that the SNP might be regularly challenged from the left by a significant group of Green and socialist MSPs has largely been averted. Arguably, the considerable rise of the Conservatives (who went from 15 to 31 seats, thereby becoming the main opposition party in Holyrood for the first time in the history of the Parliament) is a more significant result for the SNP than the rise of the Greens. One political scientist had speculated during the election campaign that "the Greens and Rise [would be] the biggest critics of the SNP by far" and that "the SNP would rather have more Conservatives because they will push for tax reduction and then the SNP can look socially democratic by comparison" ${ }^{30}$ As this article has hopefully illustrated, in its 2016 electoral campaign, the SNP targeted the middle ground more than the left, and it sought to present itself as a "responsible" party by contrast with the smaller pro-independence parties.

In the end, the fact that the 2016 Scottish Parliament election fissured what was always a superficially united pro-independence front in Scotland could be one of its most significant legacies. The "vehemence with which a hardline minority of SNP supporters have opposed the smaller parties like the Greens", ${ }^{31}$ a vehemence that was tangible in the days that followed the election in the readers' letters published in the National (an independencesupporting Scottish daily paper), makes it very doubtful whether the façade of a united independence front could be kept in the event of a second independence referendum in the near future.

Nathalie Duclos est maître de conférences HDR en civilisation britannique à l'Université Toulouse-Jean Jaurès et membre du laboratoire CAS (EA801). Sa recherche porte sur la politique écossaise contemporaine, et notamment sur le SNP, le nationalisme et l'indépendantisme en Écosse. Elle a écrit deux livres sur l'Écosse: La dévolution des pouvoirs à l'Écosse et au pays de Galles, 1966-1999 (Nantes : 
Éditions du Temps, 2007) et L'Écosse en quête d'indépendance ? Le référendum de 2014 (Paris : Presses de l'université Paris-Sorbonne, 2014), et elle a dirigé deux numéros récents de la Revue française de civilisation britannique (XX-2, 2015, "The Scottish Independence Referendum of September 2014 » et XXI-1, 2016, "Citizenship in the United Kingdom »).

\section{BIBLIOGRAPHY}

Black, Mhairi, "If you Believe in Independence, you Risk Everything Unless you Give Both Votes to the SNP", Sunday Herald, 24 April 2016.

Davidson, Jenni, “Scottish Parliament Election 2016: Manifestos and Manifesto Launches", Holyrood, 25 April 2016.

Haggerty, Angela, “In a ‘Boring' Election Campaign, Gary Tank Commander Stole the Show”, The Herald, 30 April 2016.

MacIntyre-Kemp, Gordon, "Near Certain Outcome Makes Election a Snore", The National, 29 April 2016.

Mackay, Rona, "Second Vote for Salmond", Newsnet Scotland, 4 May 2011, http://newsnet.scot/ archive/second-vote-salmond/.

Nut, Kathleen, "Sturgeon Confident on Turning No votes", The National, 21 April 2016.

Ponsonby, G.A., “Battle for the 'List' Vote: Why Backing RISE won't Help Independence”, Newsnet Scotland, 14 January 2016, http://newsnet.scot/citizen/battle-list-vote-backing-rise-wont-helpindependence/.

RISE, 2016 Scottish Parliament manifesto, Another Scotland is Possible.

RISE, “TNS Poll Shows SNP $2^{\text {nd }}$ Votes Wasted: Alan Bisset Backs RISE for a Yes Parliament”, 12 November 2015, http://www.rise.scot/blog/media/tnspoll.

Scottish Greens, 2005 Westminster election manifesto, People, Planet, Peace.

Scottish Greens, 2016 Scottish Parliament manifesto, A Better Scotland Needs a Bolder Holyrood.

Scottish Greens, “7 ways the Greens' tax plans will make Scotland fairer”, 29 March 2016, https:// greens.scot/blog/7-ways-the-greens-tax-plan-will-make-scotland-fairer.

Scottish Parliament, motion S5M-00226.4 on "Taking Scotland forward - Environment, Climate Change and Land Reform" taken on 1 June 2016.

SNP, 2015 Westminster Election manifesto, Stronger for Scotland.

SNP, 2016 Scottish Parliament manifesto, Re-elect Nicola Sturgeon.

Scottish Socialist Party, https://www.scottishsocialistparty.org/ssp-announces-party-will-standcandidates-2015-general-election/.

Solidarity, 2016 Scottish Parliament manifesto, https://solidarity.scot/solidarity-manifestoholyrood-election-5th-may-2016/. 
Sturgeon, Nicola, “My Pitch to the Scottish People”, The Herald, 17 April 2016.

Sunday Herald, "What we Want from the Next Scottish Parliament", Sunday Herald, 1 May 2016.

Swindon, Peter, “Battle under Way for Independence Supporters' List Vote at Holyrood”, Sunday Herald, 24 April 2016.

\section{NOTES}

1. The Scottish Greens' Westminster manifesto of 2005 was the first in which they officially committed to independence, "not out of nationalistic fervour, but as a means to create a more sustainable and democratic system of government" (Scottish Greens, 2005 Westminster election manifesto, People, Planet, Peace, p. 10). Until then, it had supported greater devolution and defended the principle of subsidiarity.

2. The SNP has been the majority party in Scotland since 2007. It held a relative majority of seats from 2007 to 2011, and an overall majority of seats from 2011 to 2016.

3. Angela Haggerty, "In a 'Boring' Election Campaign, Gary Tank Commander Stole the Show", The Herald, 30 April 2016. See also Gordon MacIntyre-Kemp, "Near Certain Outcome Makes Election a Snore", The National, 29 April 2016.

4. Gordon MacIntyre-Kemp, ibid.

5. Scottish Greens, 2016 Scottish Parliament manifesto, A Better Scotland Needs a Bolder Holyrood, p. 2.

6. RISE, “TNS Poll Shows SNP $2^{\text {nd }}$ Votes Wasted: Alan Bisset Backs RISE for a Yes Parliament", 12 November 2015, http://www.rise.scot/blog/media/tnspoll.

7. Rona Mackay, “Second Vote for Salmond”, Newsnet Scotland, 4 May 2011, http://newsnet.scot/ archive/second-vote-salmond/.

8. Mhairi Black, "If you Believe in Independence, you Risk Everything Unless you Give Both Votes to the SNP", Sunday Herald, 24 April 2016.

9. G.A. Ponsonby, "Battle for the 'List' Vote: Why Backing RISE won't Help Independence”, Newsnet Scotland, 14 January 2016, http://newsnet.scot/citizen/battle-list-vote-backing-risewont-help-independence/.

10. Jenni Davidson, "Scottish Parliament Election 2016: Manifestos and Manifesto Launches", Holyrood, 25 April 2016.

11. When that power came into effect, in April 2016, the Scottish Parliament decided on a $10 \%$ Scottish rate, so that Scottish taxpayers would pay exactly the same amount as English taxpayers. 12. See Nicola Sturgeon, "My Pitch to the Scottish People", The Herald, 17 April 2016.

13. To be precise, the plan was to freeze in Scotland the higher rate threshold in real terms and have it increase only in line with inflation.

14. See for instance the Scottish Greens, "7 ways the Greens' tax plans will make Scotland fairer", 29 March 2016, https://greens.scot/blog/7-ways-the-greens-tax-plan-will-make-scotland-fairer: "It isn't good enough to say Scotland won't implement Osborne's tax giveaway to the richest. Scotland can be better. (...) [O]nly by raising money fairly can we protect the public services we all need."

15. SNP, 2015 Westminster Election manifesto, Stronger for Scotland, p. 8 and p. 14.

16. Scottish Greens, 2016 Scottish Parliament manifesto, op. cit., p. 26.

17. RISE, 2016 Scottish Parliament manifesto, Another Scotland is Possible, p. 5.

18. Scottish Parliament election hustings attended by the author, Glasgow Kelvin constituency, St Mary's Cathedral, 27 April 2016.

19. See SNP, 2016 Scottish Parliament manifesto, Re-elect Nicola Sturgeon, p. 17.

20. Ibid., p. 31.

Revue Française de Civilisation Britannique, XXII-4 | 2017 
21. SNP motion S5M-00226.4 on "Taking Scotland forward - Environment, Climate Change and Land Reform" as amended by a Labour amendment, debated in the Scottish Parliament on 1 June 2016.

22. RISE, 2016 Scottish Parliament manifesto, op. cit., p. 7.

23. Solidarity, 2016 Scottish Parliament manifesto, https://solidarity.scot/solidarity-manifestoholyrood-election-5th-may-2016/.

24. Solidarity's manifesto argued that as the people of Scotland had been "subjected to a tsunami of lies, bullying, distortions and dangerously biased media reporting". See ibid..

25. See for instance Kathleen Nut, "Sturgeon Confident on Turning No votes", The National, 21 April 2016

26. SNP, 2016 Scottish Parliament manifesto, op. cit., p. 23.

27. Scottish Greens, 2016 Scottish Parliament manifesto, op. cit., p. 37.

28. SNP, 2016 Scottish Parliament manifesto, op. cit., p. 23.

29. Even though there were no united "Yes" candidates, as the SSP had wished for. See for instance https://www.scottishsocialistparty.org/ssp-announces-party-will-standcandidates-2015-general-election/.

30. Paul Cairney, quoted in Peter Swindon, “Battle under Way for Independence Supporters' List Vote at Holyrood", Sunday Herald, 24 April 2016.

31. Sunday Herald, "What we Want from the Next Scottish Parliament", Sunday Herald, 1 May 2016.

\section{ABSTRACTS}

This article examines policy divergence between the main pro-independence parties in Scotland (the Scottish National Party, the Scottish Greens, and two socialist parties/alliances: RISE and Solidarity) in the context of the 2016 Scottish Parliament election. Even though those parties are all pro-independence and leftwing, the election campaign was defined in a large part by the policy differences between them, as one of the only unknowns of the election was the scale of the SNP's expected victory and whether the smaller pro-independence parties might cost the SNP its overall parliamentary majority. The article analyses the campaign strategy of the smaller proindependence parties and the SNP's reaction to this strategy. It then looks into three issues which were at the heart of the election campaign and which are major areas of policy divergence between the SNP on the one hand, and the smaller pro-independence parties on the other hand, namely income tax, fracking and the issue of a second independence referendum. The underlying aim of the article is to examine to what extent the Scottish pro-independence parties concur beyond their convergence on the general policy aim of independence, and to question the existence of a united independence front in Scotland.

Cet article étudie les divergences programmatiques des principaux partis indépendantistes écossais (le Scottish National Party, les Verts écossais, et deux partis/alliances socialistes: RISE et Solidarity) dans le cadre des élections législatives écossaises de 2016. Bien que ces partis soient tous indépendantistes et de gauche, la campagne électorale a été en grande partie définie par les différences programmatiques entre eux, car l'une des seules inconnues des élections était l'ampleur de la victoire annoncée du SNP et si les petits partis indépendantistes pourraient priver le SNP de sa majorité absolue au Parlement écossais. Cet article analyse la stratégie de 
campagne des petits partis indépendantistes et la réaction du SNP à cette stratégie. Il se concentre ensuite sur trois questions qui furent au cœur de la campagne et sur lesquelles les programmes du SNP et des petits partis indépendantistes divergent, à savoir l'impôt sur le revenu, la fracturation hydraulique, et la question d'un second référendum sur l'indépendance écossaise. L'objectif sous-jacent de cet article est de déterminer dans quelle mesure il y a convergence entre les différents partis indépendantistes écossais au-delà de la question générale de l'indépendance, et d'interroger l'existence d'un front indépendantiste uni en Écosse.

INDEX

Mots-clés: élections législatives écossaises, partis politiques; indépendance écossaise Keywords: Scottish Parliament election, political parties, Scottish independence

\section{AUTHOR}

\section{NATHALIE DUCLOS}

CAS (EA801), Université de Toulouse-Jean Jaurès 